\title{
Article \\ Land Degradation, Overland Flow, Soil Erosion, and Nutrient Loss in the Eastern Himalayas, India
}

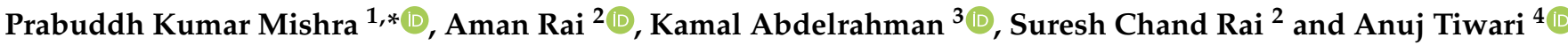 \\ 1 Department of Geography, Shivaji College, University of Delhi, New Delhi 110027, India \\ 2 Department of Geography, Delhi School of Economics, University of Delhi, Delhi 110007, India; \\ arai@geography.du.ac.in (A.R.); scrai@geography.du.ac.in (S.C.R.) \\ 3 Department of Geology and Geophysics, College of Science, King Saud University, \\ Riyadh 11451, Saudi Arabia; khassanein@ksu.edu.sa \\ 4 Discovery Partner Institute, University of Illinois Systems, Chicago, IL 60606, USA; anuj@uic.edu \\ * Correspondence: prabuddh@shivaji.du.ac.in
}

check for

updates

Citation: Mishra, P.K.; Rai, A.;

Abdelrahman, K.; Rai, S.C.; Tiwari, A Land Degradation, Overland Flow, Soil Erosion, and Nutrient Loss in the Eastern Himalayas, India. Land 2022, 11, 179. https://doi.org/10.3390/ land11020179

Academic Editors: Angelinus Franke, Mirko Castellini, Vincent Chaplot and Manuel Pulido Fernádez

Received: 19 November 2021

Accepted: 20 January 2022

Published: 23 January 2022

Publisher's Note: MDPI stays neutral with regard to jurisdictional claims in published maps and institutional affiliations.

Copyright: (C) 2022 by the authors. Licensee MDPI, Basel, Switzerland. This article is an open access article distributed under the terms and conditions of the Creative Commons Attribution (CC BY) license (https:// creativecommons.org/licenses/by/ $4.0 /)$.

\begin{abstract}
Studies on the assessment of land degradation, overland flow, soil loss, and nutrient loss have emerged as paramount importance for food security and rural livelihood in the mountains. The present study dealt with similar issues in the Eastern Himalayas, for which the primary data were collected from the field during 2017-18. Quantitative and qualitative methods were used to collect data on soil erosion and information on overland flow, soil loss, and nutrient loss was assessed through field experiments in the watershed of Sikkim, Eastern Himalayas. The first section of the methodology deals with the experimental analysis from different land use categories to quantify soil loss. In the second section, detailed qualitative analyses of farmers' perceptions of soil erosion indicators were recorded through field surveys, i.e., key informant interviews (KEIs) and focus group discussions (FDGs). The results showed that the highest overland flow was in barren land $(8.63 \%)$ followed by large cardamom-based agroforestry system (7.02\%), and mixed cropping (4.84\%), and the lowest overland flow was in terrace cultivation $(4.69 \%)$. Soil loss was estimated to be the highest for barren land (7.73 Mg/ha/year (megagram/hectare/year)) followed by mixed cropping (4.32 Mg/ha/year), and terrace cultivation (3.75 Mg/ha/year), with the least soil loss estimated to be in cardamom-based agroforestry (3.23 Mg/ha/year). Loss of nitrogen $(\mathrm{N})(4.49 \mathrm{~kg} / \mathrm{ha} /$ year $)$ and phosphorous $(\mathrm{P})(2.43 \mathrm{~kg} / \mathrm{ha} /$ year) were highest in barren land, while potassium (K) loss was highest (4.30 kg/ha/year) in mixed farming. The lowest $\mathrm{N}$ loss rate $(3.34 \mathrm{~kg} / \mathrm{ha} /$ year $)$ was in terrace cultivation, the lowest $\mathrm{P}$ loss rate $(8.19 \mathrm{~kg} / \mathrm{ha} /$ year $)$ was in mixed farming, and the lowest potassium loss rate (3.28 kg/ha/year) was in cardamom-based agroforestry. Approximately $33 \%$ of the farmers acknowledged light or no soil losses, while $17 \%$ of the farmers accepted moderate soil erosion. The results of field survey indicated that only $15-19 \%$ of the farmers reported high or extreme soil loss in the fields. Farmers in the watershed are practicing multiple measures to control land degradation; however, marginal farmers are still vulnerable and need strong support from the government to safeguard their land.
\end{abstract}

Keywords: land degradation; soil loss; nutrient loss; watershed; Eastern Himalayas

\section{Introduction}

Land degradation in the form of soil erosion is a global phenomenon that causes nutrient loss and is a major hurdle to agricultural production and sustainable agricultural development. Water, wind, ice, and gravity wear away rock to form soil and shape the ground surface through geological erosion, often known as "natural" erosion.

It is a long, gradual process that goes undetected most of the time. Accelerated erosion is the process of soil materials being detached and transported by water, wind, ice, and gravity as a result of human activity. Even though erosion is as old as agriculture, its 
magnitude has increased significantly [1,2]. Land degradation has a negative impact on people's livelihoods and affects one-quarter of the ice-free land area on the planet. The vast majority of the 1.3 to 3.2 billion individuals impacted live in poverty in developing nations [3]. According to the FAO-led Global Soil Partnership [4], 75 billion ton (Pg) of soil is eroded annually from agricultural areas throughout the world, resulting in a financial loss of 400 billion USD each year. Rainfall and overland flow are the primary causes of soil erosion and nutrient loss, resulting in soil sterility, productivity decrease, and ecological degradation $[5,6]$. Soil erosion is of various types including sheet erosion, water erosion, mass erosion, landslide, terrace failure, and so on. Vegetation removal, road and building development, mining, and hydropower project construction have all contributed to the human-induced intensification of land sliding [7]. Reduced crop productivity and decreased surface water quality have been shown to be consequences of soil loss on agricultural land $[8,9]$. Soil erosion decreases agricultural production, water quality, soil fertility, and impact hydrology and environmental sustainability $[10,11]$. Soil erosion and nutrient loss are linked, and one of the issues influencing sustainable agriculture is soil erosion. Soil erosion has been attributed to human-induced soil erosion, increased deforestation, overgrazing, wildfire, and unsuitable land use practices worldwide [12-14].

About 175 million hectares of India's 328 million hectares of land are experiencing severe soil erosion as a result of massive deforestation and inadequate land management; the Shiwaliks and the Lesser Himalayas are two of the most severely affected areas [15]. The Himalayas' steep slopes, decreased forest cover, and high seismicity are key elements in river run soil erosion and sedimentation [16]. The hydrology of the basin has been changing dramatically as a result of soil erosion and floods in the Himalayan River basins that are transboundary [17], and the challenges have been intensified by social, economic, and political developments [18]. According to ICIMOD [19], the decline of forest/pasture regions, landslides, mudslides, terrace failure, and soil loss from steep slopes are the main causes of land degradation in the Himalayan region. Numerous studies have been conducted to assess soil erosion in the central Himalayas that focused on the middle Mountain region [20], while few studies have focused on the High Himalayas [21-23]. In the northeastern Himalayan region alone, water erosion has resulted in $601 \mathrm{Mt}$ of soil loss and $685.8,99.8,511.1,22.6,14.0,57.1$, and 43.0 thousand tons of nitrogen, phosphorus, potassium, manganese, zinc, calcium, and magnesium, respectively [24]. Soil erosion rates vary depending on the terrain, slope, land use practices, and population pressure in different physiographic regions. Sediment losses from different LULC classes fluctuate significantly because of soils, geology, vegetation, and slope.. Agricultural crop production, for example, accelerates soil erosion, resulting in stream water quality degradation due to the accumulation of soil sediments in the water bodies [25], while soil loss under vegetative cover and in forested areas is generally very minimal $[26,27]$. Therefore, it is important to understand the status of soil erosion in different land covers for estimating soil erosion in highly vulnerable and comparatively minimal soil erosion areas. If the magnitude and spatial distribution of soil erosion risk areas are identified, management practices to reduce soil erosion can be carried out successfully. The majority of current studies have been focused on erosion modeling using various automated processes and toolboxes for soil erosion estimation with the help of modern geospatial technology [28,29]. Some of the studies have also focused on soil loss potential under the context of climate change for predicting future soil loss $[30,31]$. However, the present study attempts to assess the rate of soil erosion by using only field data and the perceptions of local farmers regarding soil erosion and measures of soil conservation. There have been very few attempts to estimate soil erosion from different land covers in the eastern Himalayan region. In the studied watershed, organic farming is practiced on terraced slopes; small landholdings on steep slopes are prone to soil erosion, especially, in the rainy season. Hence, this study was conducted to assess the rate of soil loss from different land covers during the rainy season and to investigate the factors driving erosion rates. 
Studies have shown that forests and vegetated areas check soil erosion more efficiently than any other land use type due to litter and vegetation canopy interception [32]. However, there are few experimental studies available that have highlighted the role of various land use practices in evaluating land degradation, overland flow, soil erosion, and nutrient loss processes $[33,34]$. Thus, this study aimed to experimentally quantify soil erosion and surface runoff in the mountainous watershed of Sikkim, Eastern Himalayas. In this study, we obtain original data on soil erosion in the region, provide insights into how farmers perceive soil erosion in the region and the measures they use to minimize soil erosion of their agricultural lands.

\section{Material and Methods}

\subsection{Study Area}

The research was carried out in the Rani Khola watershed of Sikkim, in India's Eastern Himalayas. With an area of approximately $254 \mathrm{~km}^{2}$, the watershed is located between $27^{\circ} 13^{\prime} 9-27^{\circ} 23^{\prime} 51 \mathrm{~N}$, and $88^{\circ} 29^{\prime} 31-88^{\circ} 43^{\prime} 18 \mathrm{E}$. (Figure 1 ). The elevation of the watershed varies from 311 to $4112 \mathrm{~m}$ above sea level. The temperature varies with altitude and slopes, and ranges from 0 to $26^{\circ} \mathrm{C}$, generally decreasing with increasing altitude. With intensity ranging from drizzling to torrential rain, the average annual rainfall is approximately $3300 \mathrm{~mm}$ and most of the rainfall occurs during the monsoon season (July-September). Three agro-ecological zones were delineated based on physical and agricultural criteria in a geospatial environment in the study area [35]. The analyses of agro-ecological zones were based on a different set of information, namely altitude, climate, major crops, irrigation, and agricultural practices. The villages were selected from all ecological zones for the questionnaire survey and are shown in Figure 1. As per the requirements of the study, the watershed was classified into three distinct agro-ecological zones, i.e., high, medium, and low. Each agro-ecological zone is characterized by different cropping patterns, as well as different crop productivity levels and land management practices. The low ecological zone falls under tropical climate and covers the smallest area in the watershed, while the mid ecological zone falls in the subtropical and high ecological zone in temperate climate and covers the largest area of the watershed.

\subsection{Data Collection and Analysis}

For the collection of data on soil erosion, both quantitative and qualitative methods were applied. Information on overland flow, soil loss, and nutrient loss was assessed through field experiments in the watershed area. The first section of the methodology deals with the experimental analysis from four land use categories to quantify soil loss. In the second section, detailed qualitative analyses of farmers' perceptions of soil erosion indicators were recorded through field surveys, key informant interviews (KEIs), and focus group discussions (FDGs). To characterize soil erosion, an integrated approach was adopted, details of which are provided in the following subsections. Overall methodological framework and data analysis is presented in Figure 2. 

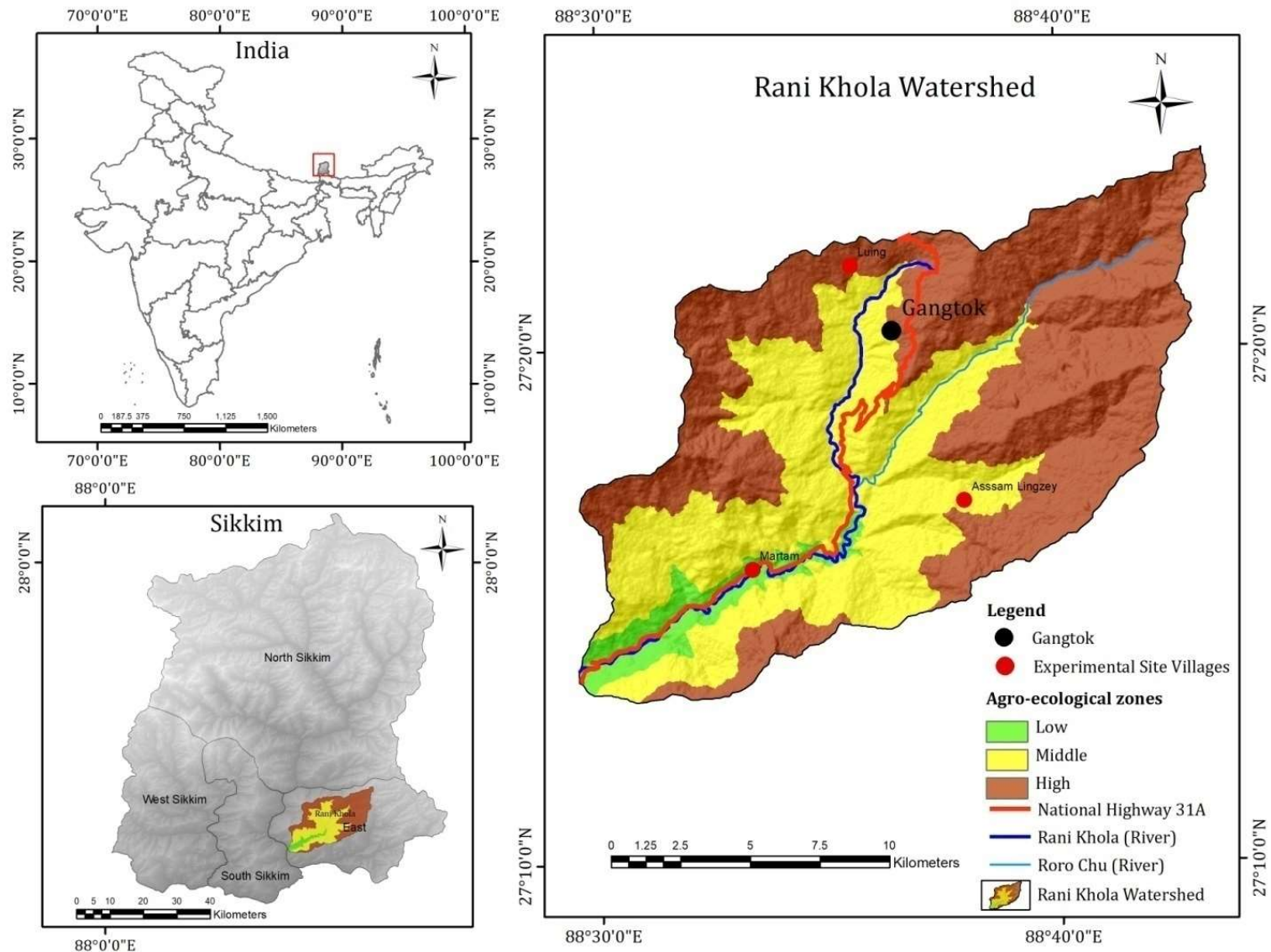

Figure 1. Base map of the study area.

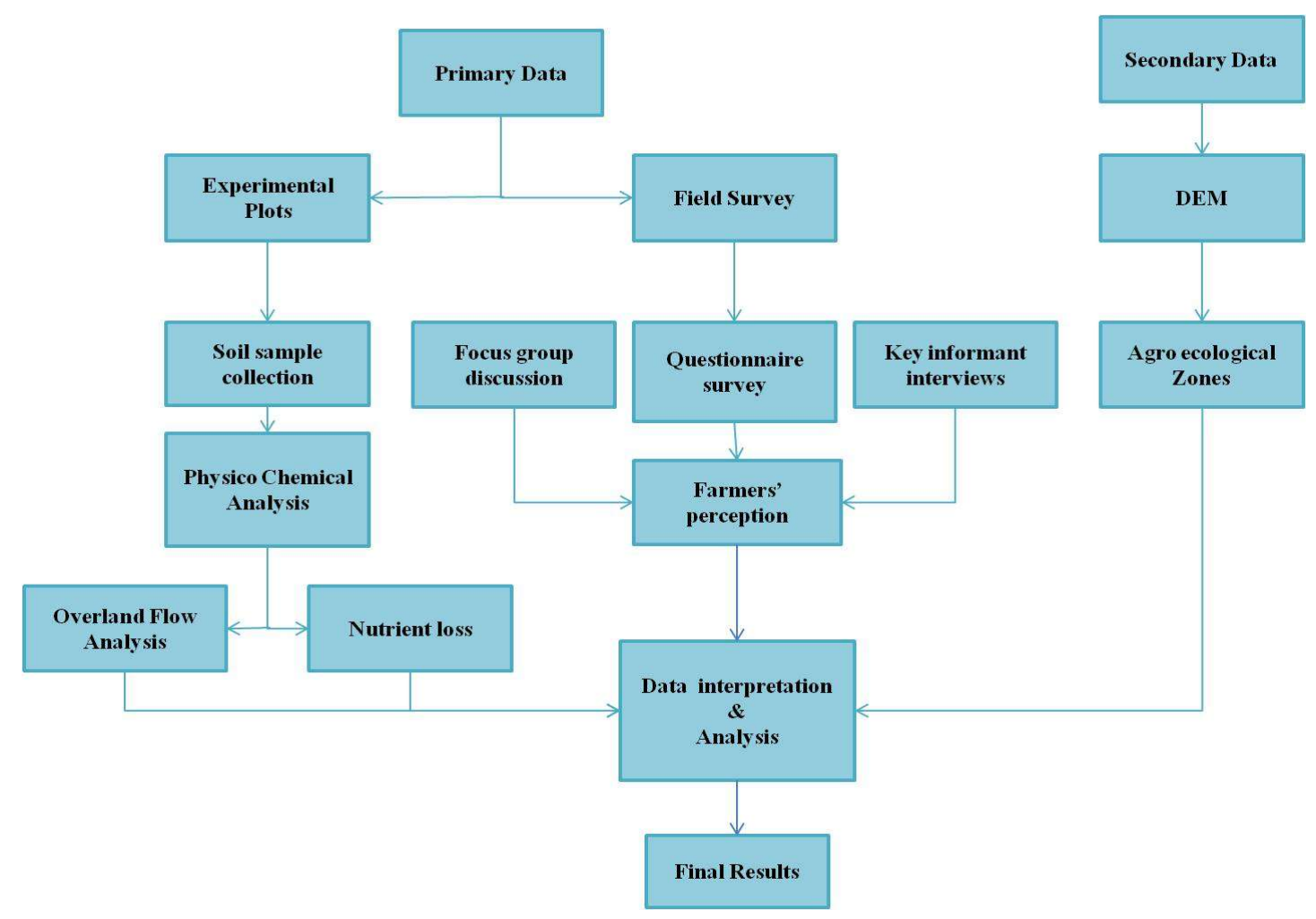

Figure 2. Methodology and data sources used in the study. 


\subsubsection{Soil Sample/Soil Physical Properties}

Soil samples were collected from a total of 12 locations covering 4 experimental plots in each land use and land cover type in each ecological zone. The soil samples were taken in triplicate from the high, mid, and low zones, and sampling points were chosen from the vicinity of the delineated plots. A single sample of around $100 \mathrm{~g}$ was taken from a depth of up to $15 \mathrm{~cm}$ at each location, sealed in a plastic bag, and submitted to the lab for chemical and physical testing. These samples were taken shortly before the rainy season, during plot demarcation, and were categorized as parent soil.

\subsubsection{Overland Flow, Soil Loss, and Nutrient Loss Data}

Overland flow, soil loss, and nutrient loss were estimated from four land use practices, i.e., barren land, terrace farming, agroforestry, and mixed farming, from 3 ecological zones namely high, mid, and low.

\subsubsection{Experimental Design}

In the experimental station, twelve runoff sites were built after soil samples were collected. These were calculated using artificially delineated plots and natural shallow surface runoff channels $[36,37]$. For the assessment of overland flow, soil loss, and nutrient loss, $3 \times 3 \mathrm{~m}$ plots were defined; one plot was constructed in each type of land use practice in each ecological zone. These plots were lined on all sides with aluminum sheets (approximately $6 \mathrm{~cm}$ inserted in the soil and the remaining $15 \mathrm{~cm}$ exposed in the air) to prevent water from entering from the surrounding areas. After each rainfall event, these collection tanks were used to assess the overland flow and soil loss along the slope.

\subsubsection{Measurements Methods}

A rain gauge cylinder was used to record rainfall. A ruler was used to measure the water level in each tank after each rainfall event. The eroded soil was collected in the collecting tank as suspended clay material and bed-load sediment. Filtration was performed on the suspended clay material from the sample water using Whatman filter paper. The losses were calculated on a unit area basis and the total loss from each land use category was extrapolated. Soil nutrients from two depths $(0-15 \mathrm{~cm})$ were tested under various land uses to investigate the impact of land use on soil fertility and nutrient levels. The nutrients organic carbon, total nitrogen, total potassium, and total phosphorus were measured using physico-chemical examination of parent soil and eroded soil samples. The physical efficiency of the terrace cultivation, mixed farming, and large cardamom-based agroforestry practices in terms of soil and water retention were examined with and without conservation measures in these experiments. Additional information on the physical effects of SWC measures was documented from a household survey of the watershed. The reports were validated, updated, and some missing material was collected through discussions with extension workers and innovative farmers.

\subsection{Assessment of Farmers' Perceptions of Soil Erosion}

Additional assessment of soil loss was assessed through farmers' perceptions. To overcome the problem of data scarcity and evaluate soil erosion in a relatively short period, a unique approach for assessing land degradation from the standpoint of farmers was used. It was based on farmer assessments and observations of changes in their fields. These changes were expressed as soil and productivity loss through visible and comprehensible indicators by the farmers. For the field survey, three villages were selected from each ecological zone. A total of 300 questionnaires and 9 FGDs were performed in nine villages from each ecological zone, i.e., high, mid, and low, for the assessment of soil erosion indicators during the year 2017-18. The villages were selected based on their agriculture practices and accessibility. Of the total participants in FGDs, 35\% of respondents were female. The FGDs consisted of a mixture of closed- and open-ended questions. Farmers were asked open-ended questions, thereby, providing participants with an ample opportunity to ex- 
press their views. Five primary and eight supplementary soil loss indicators were chosen from the Stocking and Murnaghan's list for soil loss [38]. Indicators of land degradation were presented and explained to farmers during the discussion and the farmers were asked to identify the indicators of land degradation, causes, and management strategies to tackle the problem. The major issues included in the FGDs were farmers' perceptions and knowledge of erosion occurrence; soil erosion and productivity levels were categorized into five classes ranging from none to extreme soil loss. Additional information was also collected through informal discussions with innovative farmers and agriculture extension officers to complement and crosscheck the information provided.

\subsection{Characteristics of Respondents and Sample Villages}

Agriculture is the main activity of the watershed as a majority is rural. Cultivators constitute around $24.03 \%$ of the working population, while agricultural laborers constitute about $5.04 \%$. According to data collected in a field survey, about $71.33 \%$ of respondent families are nuclear, with an average household size of four people. In the whole watershed, about $47 \%$ of respondents are marginal farmers with less than 0.5 hectares of land, while $30 \%$ are medium-sized landholding farmers and $22.66 \%$ are big landholding farmers. Animal traction is mostly utilized for land preparation; however, because only a few people own a pair of oxen, they are rented to other farms in exchange for labor. The majority of the watershed's families do not have fallow seasons in their agricultural rotation. As a result of this, as well as other constraints such as low-quality seeds and low planting density, traditional agriculture methods have been lost, and agricultural productivity levels in this region are often extremely low, making soil and water conservation a pressing concern.

Martam, Assam Lingzey, and Luing are the important villages and were carefully selected as experimental villages, to obtain a representative sample of villages for the whole watershed (Figure 1). Table 1 shows the most substantial geographical, climatic, cultural, and socioeconomic variations among the selected villages. In all the villages, irrigation potential is limited, and agriculture is primarily rainfed. In all of these villages, the majority of households still practice mixed farming, with mostly subsistence crops and a herd of cows and goats. The majority of the households reported that soils were becoming less productive and had lost much of their previous production capability [39]. Maize, paddy, ginger, vegetables, and cardamom are still the main crops, among which paddy, ginger and vegetables require manure. Other important crops are millet and potato.

Table 1. Characteristic features of sampled villages of the watershed.

\begin{tabular}{cccc}
\hline Elements & Martam (Low) & $\begin{array}{c}\text { Assam Lingzey } \\
\text { (Mid) }\end{array}$ & Luing (High) \\
\hline No. of Household & 776 & 430 & 413 \\
\hline Population $(\mathrm{no})$ & 3720 & 2055 & 2019 \\
\hline Slope $\left(^{\circ}\right)$ & $20-25$ & $20-25$ & $25-30$ \\
\hline Topography & V shaped & V shaped & V shaped \\
\hline Altitude $(m)$ & $500-600$ & $900-1200$ & $1900-2000$ \\
\hline Water availability & Good & Good & Moderate \\
\hline Agriculture & Subsistence/commercial Subsistence/commercial Subsistence/agroforestry \\
\hline
\end{tabular}

\subsection{Erosion in the Watershed}

Soil erosion occurs slowly over geologic time, but its cumulative effects on soil quality over billions of years have been enormous. The mountainous topography of the watershed is characterized by ridges and ravines generally with sharp narrow crests and deep Vshaped valleys having varying slope segments. Within the region, there is a lot of variety in terrain and land use practices, which results in diverse types of land degradation. Different ecological zones of the watershed experience different forms of land degradation. 
Landslides, mass wasting, rill erosion, gully erosion, and soil erosion from agricultural lands is dominant in the high ecological zone which covers $54.27 \%$ of the watershed, while in the lower ecological zone which covers $5.56 \%$ of the area, sheet erosion, rills, riverbank expansion, and soil erosion from agricultural lands are major types of land degradation. Landslides, rill erosion, gully erosion, and soil erosion from agricultural lands are prevailing types of land degradation in the mid ecological zone which covers about $40.17 \%$ area [35]. The severity of the problem is determined by several factors, including slope, plant cover, soil type, and rainfall intensity. Land use and land cover also play a major role in soil erosion. The area under dense and open forest covers $74.75 \%$ collectively, agricultural land cover $17.63 \%$, built-up area cover $4.95 \%$, and barren land cover $2.56 \%$ of the watershed [40]. Landslides and slope collapse are common in the upper ecological zones with vegetationfree regions with steep slopes that come under barren land, whereas the damage is restricted to soil erosion on the gentler slopes. One of the major concerns of soil erosion emerges from agricultural land where, during the rainy season, farmers have reported soil loss and nutrient loss from the watershed. During the monsoon season, the intensity of sheet erosion is increased in all ecological zones' barren areas. Farmers said the most prevalent types of land degradation in the watershed include landslides, mass wasting, slope or terrace failure, rill erosion, sheet erosion, riverbank expansion, and soil erosion from agricultural land during focus group discussions. Slope failure, gully and sheet erosion, etc. are other issues identified by the farmers. Soil erosion, seasonal water shortages, rising population, poverty, and small landholdings are the major hurdles in agricultural production, and farmers are well aware of the situation since the declining productivity of soil affects the financial well-being of the farmers. Farmers make investments in their fields by practicing several indigenous SWC measures such as mechanical, biological, and soil fertility measures to check soil erosion. Farmers' first preferences among the various conservation measures adopted and practiced were agronomic treatment measures. These measures are often less costly and effectively manage raindrop impact, runoff volumes, and water velocity while enhancing infiltration and organic matter in the soil profile. Farmers stated that agronomic measures, such as planting bamboo trees, had been employed to avoid slope failure, gully erosion, and landslides not just on agricultural land, but also in the watershed's most unstable and vulnerable locations.

\section{Results and Discussion}

\subsection{Physico-Chemical Properties of the Soil}

The physico-chemical properties of soil characteristics are critical for determining the soil quality of a certain location, and this was done for the study watershed. Table 2 shows the findings of the soil samples as well as the values of the selected indicators, such as bulk density, water retention capacity, texture, and chemical and fertility parameters, for various land use classes. In soil samples gathered from the various land use/experimental sites, there was a little variation in bulk density values. The mean bulk density for the barren land was significantly high as compared with other land use types (Table 2). The mixed cropping, cardamom-based agroforestry and terrace cultivation had low BD, indicating that the soil was good for cultivation and vegetation growth as compared to barren land. Higher values of bulk density were observed in the barren land, because of poor organic matter and poor soil aggregation. The soil organic matter was observed highest in cardamom-based agroforestry and mixed farming followed by terrace cultivation and barren land [41,42]. The barren land showed less organic matter than other land use types because of less vegetation and litter. A description of the land use types used in experimental sites are given in Table 3 and pictures of selected sites are shown in Figure 3. 
Table 2. Physico-chemical characteristics of soil samples in deferent land use classes.

\begin{tabular}{|c|c|c|c|c|}
\hline $\begin{array}{c}\text { Soil } \\
\text { Samples }\end{array}$ & $\begin{array}{c}\text { Mixed } \\
\text { Cropping } \\
(n=4)\end{array}$ & $\begin{array}{c}\text { Cardamom-Based } \\
\text { Agroforestry } \\
(n=4)\end{array}$ & $\begin{array}{c}\text { Terrace } \\
\text { Cultivation } \\
(n=4)\end{array}$ & $\begin{array}{c}\text { Barren } \\
\text { Land } \\
(n=4)\end{array}$ \\
\hline \multicolumn{5}{|c|}{ Physical Parameters } \\
\hline $\mathrm{BD}(\mathrm{gm} / \mathrm{cc})$ & 1.12 & 1.13 & 1.01 & 1.41 \\
\hline WRC (\%) & 53.92 & 57.21 & 58.2 & 39.1 \\
\hline \multicolumn{5}{|c|}{ Texture } \\
\hline Sand $(\%)$ & 32.82 & 31.45 & 32.24 & 45.71 \\
\hline Clay $(\%)$ & 16.35 & 15.82 & 14.47 & 17.3 \\
\hline Silt (\%) & 47.83 & 52.73 & 53.29 & 68.21 \\
\hline \multicolumn{5}{|c|}{ Chemical Parameters } \\
\hline $\mathrm{pH}$ & 5.8 & 5.3 & 5.6 & 6.1 \\
\hline OC (\%) & 12.22 & 13.43 & 9.88 & 6.21 \\
\hline $\mathrm{N}(\mathrm{kg} / \mathrm{ha})$ & -183 & 157.5 & 174 & 153 \\
\hline $\mathrm{P}(\mathrm{kg} / \mathrm{ha})$ & 49.5 & 43.5 & 34.5 & 40.5 \\
\hline $\mathrm{K}(\mathrm{kg} / \mathrm{ha})$ & 166.53 & 196.5 & 218.82 & 153.46 \\
\hline $\mathrm{Mg}(\mathrm{mg} / \mathrm{kg})$ & 132.51 & 138.11 & 162.00 & 112.27 \\
\hline
\end{tabular}

$\mathrm{BD}$, bulk density; $\mathrm{WRC}$, water retention capacity; $\mathrm{OC}$, organic carbon; $\mathrm{N}$, nitrate (as $\left.\mathrm{NO}_{3}\right)$; $\mathrm{P}$, phosphates; $\mathrm{K}$, potassium; $\mathrm{Mg}$, magnesium; $\mathrm{kg} / \mathrm{ha}$, kilogram per hectare.

Table 3. Description of land use types used in experimental sites.

\begin{tabular}{|c|c|c|c|c|c|}
\hline $\begin{array}{c}\text { Land Use } \\
\text { Types }\end{array}$ & Use & Soil Type & Slope & $\begin{array}{l}\text { Major Land } \\
\text { Degradation } \\
\text { Types }\end{array}$ & $\begin{array}{c}\text { Conservation } \\
\text { Types }\end{array}$ \\
\hline $\begin{array}{l}\text { Mixed } \\
\text { cropping }\end{array}$ & $\begin{array}{c}\text { Major crops are } \\
\text { maize and } \\
\text { vegetables }\end{array}$ & Sandy loam & Gentle & $\begin{array}{l}\text { Soil erosion, } \\
\text { sheet erosion }\end{array}$ & $\begin{array}{c}\text { Mixed } \\
\text { cropping } \\
\text { intercropping, } \\
\text { and vegetative } \\
\text { barriers }\end{array}$ \\
\hline $\begin{array}{c}\text { Terrace } \\
\text { cultivation }\end{array}$ & $\begin{array}{c}\text { Major crop are } \\
\text { paddy, ginger, and } \\
\text { maize }\end{array}$ & $\begin{array}{l}\text { Silty-clay } \\
\text { loam }\end{array}$ & Stable/leveled & Terrace failure & $\begin{array}{c}\text { Earthen bunds, } \\
\text { stone Bunds, } \\
\text { and vegetative } \\
\text { barriers }\end{array}$ \\
\hline $\begin{array}{l}\text { Cardamom- } \\
\text { based } \\
\text { agroforestry }\end{array}$ & $\begin{array}{l}\text { Major crops are } \\
\text { agroforestry and } \\
\text { horticulture, other } \\
\text { fruits, and fodder } \\
\text { crops }\end{array}$ & Sandy loam & Moderate & Overland flow & $\begin{array}{l}\text { Agroforestry, } \\
\text { minimum } \\
\text { tillage, and } \\
\text { vegetative } \\
\text { barriers }\end{array}$ \\
\hline Barren Land & $\begin{array}{l}\text { Agricultural fallow } \\
\text { land not in use } \\
\text { from the previous } \\
\text { year }\end{array}$ & Silty loam & Moderate & $\begin{array}{l}\text { Soil erosion, } \\
\text { sheet erosion, } \\
\text { rills, gully } \\
\text { erosion, } \\
\text { landslides }\end{array}$ & Fallowing \\
\hline
\end{tabular}




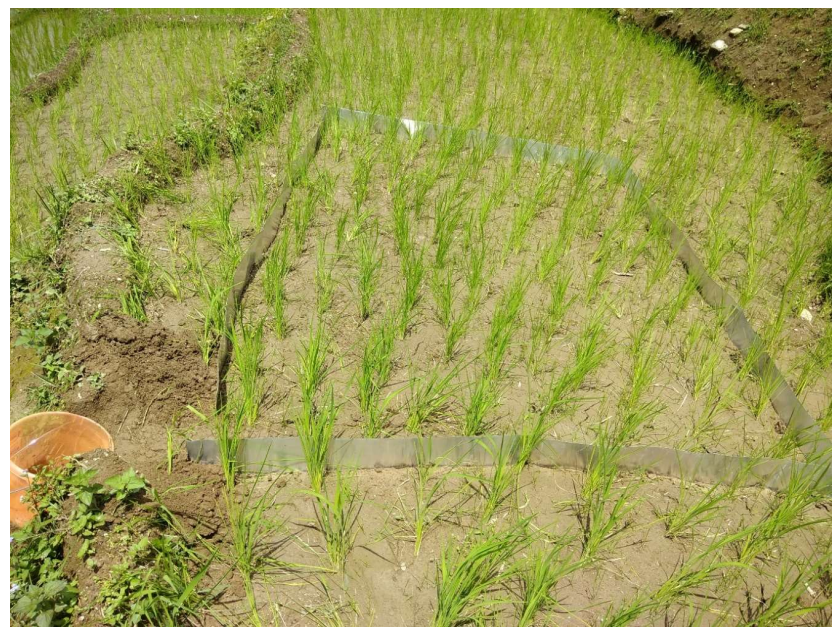

(A)

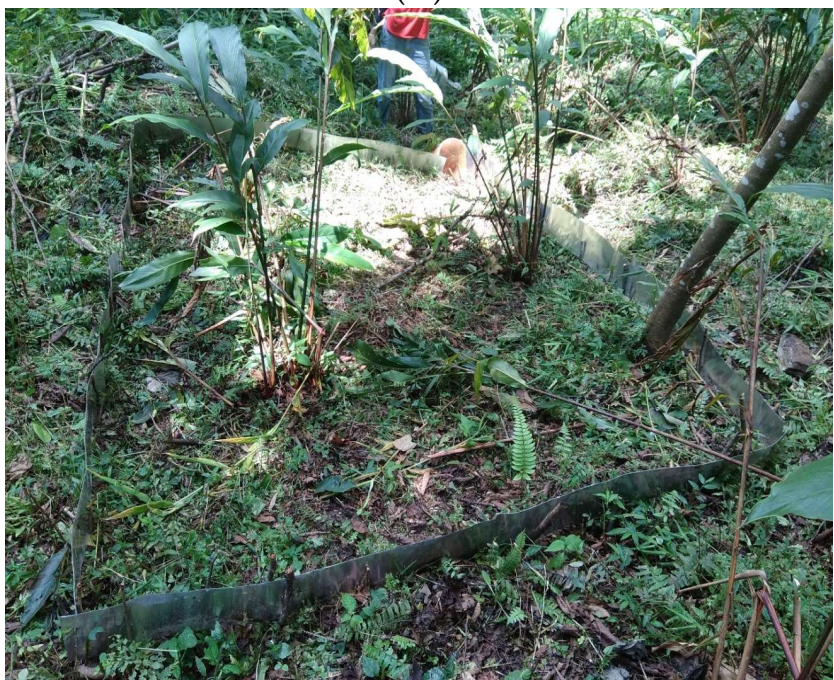

(C)

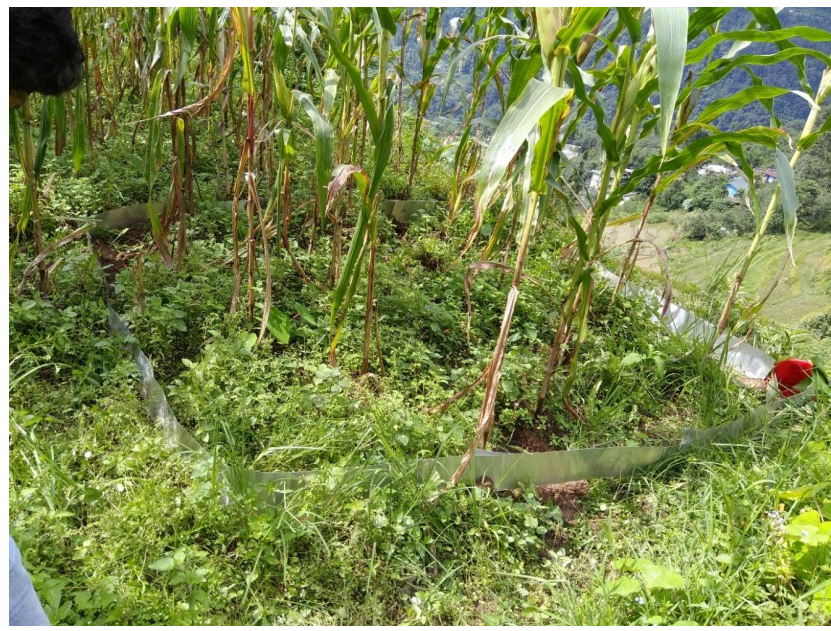

(B)

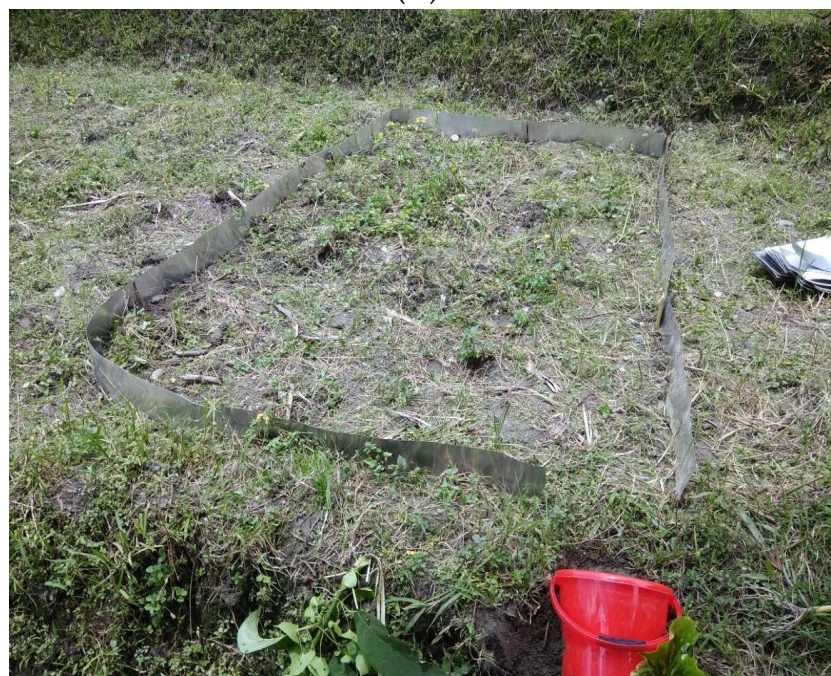

(D)

Figure 3. Runoff sites: (A) terrace cultivation; (B) mixed farming; (C) agroforestry; (D) barren land.

\subsection{Precipitation, Total Runoff, Soil Loss, and Nutrient Loss}

The majority of the area in the watershed falls under forest land use [40], however, agricultural areas are affected by raindrop splash and sheet erosion, and further, it intensifies on the sloping land. Precipitation was recorded at three locations covering each ecological zone (low, mid, and high) for three rainfall events. The total precipitation recorded with the help of a rain gauge was $990 \mathrm{~mm}$. The data regarding the total runoff, soil loss, and nutrient loss were collected from different land uses/land cover classes during the monsoon season and the results from three rainfall events during the year 2017 are presented in Tables 4 and 5. The maximum soil loss values were recorded in barren land followed by cardamom-based agroforestry, whereas mixed cropping and terrace cultivation recorded the least amount of soil loss from the watershed. Various studies have also established the fact that the overland flow was highest in the barren lands, followed by agroforestry and mixed farming, and a similar result has been observed in the study watershed $[43,44]$. The reason for less soil loss on the sloppy land was because indigenous soil and water conservation measures had been widely practiced to conserve soil loss. As for other SWC practices are concerned agroforestry practices have performed better than other practices. Terrace cultivation was also identified as a top measure for reducing soil erosion and results from the analysis confirmed the perceptions of the farmers. 
Table 4. Overland flow and soil loss under different land uses at the experimental sites.

\begin{tabular}{cccc}
\hline Land Use/Land Cover & $\begin{array}{l}\text { Overland Flow } \\
\text { (\% of Rainfall) }\end{array}$ & Soil Loss (Kg/ha) & $\begin{array}{c}\text { Soil Loss } \\
\text { (Mg/ha/year) }\end{array}$ \\
\hline Mixed cropping & 4.84 & 141 & 4.32 \\
\hline Terrace cultivation & 4.69 & 130 & 3.75 \\
\hline Cardamom-based agroforestry & 7.02 & 126 & 3.23 \\
\hline Barren land & 8.63 & 278 & 7.73 \\
\hline
\end{tabular}

Values of overland flow and soil loss are the mean of four samplings, calculated for 3 rainfall events in the year 2017. * Mg, megagrams (tons).

Table 5. Overland flow and nutrient loss at the experimental sites.

\begin{tabular}{cccccc}
\hline \multirow{2}{*}{$\begin{array}{c}\text { Land Use/Land } \\
\text { Cover }\end{array}$} & $\begin{array}{c}\text { Overland Flow } \\
\text { (\% of Rainfall) }\end{array}$ & $\begin{array}{c}\text { Organic } \\
\text { Carbon (\%) }\end{array}$ & $\begin{array}{c}\text { Nitrogen } \\
\mathbf{( N )}\end{array}$ & $\begin{array}{c}\text { Phosphorous } \\
\mathbf{( P )}\end{array}$ & $\begin{array}{c}\text { Potassium } \\
\mathbf{( K )}\end{array}$ \\
\hline Mixed cropping & 4.84 & 1.41 & 3.45 & 8.19 & 4.30 \\
\hline $\begin{array}{c}\text { Terrace } \\
\text { cultivation }\end{array}$ & 4.69 & 1.54 & 3.34 & 2.35 & 3.43 \\
\hline $\begin{array}{c}\text { Cardamom- } \\
\text { based } \\
\text { agroforestry }\end{array}$ & 7.02 & 1.83 & 3.76 & 1.59 & 3.28 \\
\hline \begin{tabular}{c} 
Barren land \\
\hline Values calculated for experimental plots under different land uses.
\end{tabular} & & & & \\
\hline
\end{tabular}

\subsubsection{Total Runoff}

The barren land $(8.63 \%)$ had the greatest total runoff (rainfall \% during the rainy season for the same time), where there was no vegetation or grasses, and therefore, it was prone to erosion during the rainy season. Terrace cultivation had the lowest overland flow $(4.69 \%)$, followed by mixed cropping $(4.84 \%)$ in the watershed. The second highest runoff was recorded for the large cardamom-based agroforestry system $(7.02 \%)$, which was mainly because of the steep slope, newly planted saplings, and application of farmyard manure (FYM). The difference in overland flow under different land uses/land covers depended on the capacity to stand against the erosional power of rainfall. It has been observed that barren land or land without significant vegetation cover usually has higher runoff as compared with the areas having a higher degree of vegetation cover. Similar results have been observed in a study conducted in south Sikkim [44].

\subsubsection{Soil Loss}

In the context of soil loss, the data revealed that, in most of the cases, soil loss followed the rate of overland flow. Soil loss was the least in the cardamom-based agroforestry (3.23 Mg/ha/year) followed by terrace cultivation ( $3.23 \mathrm{Mg} / \mathrm{ha} /$ year), mainly due to the fact that the plants could interrupt rainfall and reduce sheet and splash erosion and the soil binding capacity of the roots could also stabilize the soil. High soil loss was observed from the barren land where runoff was also high, because of the lack of vegetative cover and non-application of SWC measures. The values for soil loss recorded for land under terrace cultivation were significantly lower than those for barren and open lands, due to stone bunding and slope reduction (Table 4). The soil loss data showed that the application of indigenous SWC techniques were worthwhile and successful in minimizing soil loss as compared with the areas where SWC practices had not implemented. Soil loss was estimated to be the highest for barren land $(7.73 \mathrm{Mg} / \mathrm{ha}$ /year) followed by mixed cropping (4.32 Mg/ha/year). It was also observed that the higher the slope length, the greater the erosion. Other factors such as rainfall intensity and duration, soil moisture, and geological setting also influenced runoff and soil erosion. 


\subsubsection{Nutrient Loss}

Nutrient loss takes place through overland flow and soil loss; indigenous SWC measures play an essential role in reducing soil loss and nutrient loss. The nutrient losses under different land uses/land covers in the watershed are shown in Table 6. The results of the nutrient test of eroded soil show that available phosphorus was significantly high and total nitrogen was medium in all the land uses/land covers in the study fields. The concentrations of all the nutrients in eroded soil (N, C, P, and K) were higher because of the nutrient-rich soil and the samples were collected after the application of the FYM and preparation of the fields, except for the barren land samples. Organic carbon was also high in the eroded as well as parent soil for the land uses/land covers.

Table 6. Soil loss indicators for assessing land degradation in the watershed.

\begin{tabular}{|c|c|c|c|c|c|}
\hline S. No & Erosion Indicators & Occurrence & Indicators for & Causes & Measures \\
\hline \multicolumn{6}{|c|}{ Major Indicators } \\
\hline 1. & Rills formation & Yes & Past soil losses & $\begin{array}{l}\text { Overland flow and } \\
\text { increased runoff }\end{array}$ & Gully growth \\
\hline 2 & Gullies formation & Yes & Past soil losses & $\begin{array}{l}\text { Overland flow and } \\
\text { runoff, additional } \\
\text { runoff from leaking } \\
\text { irrigation channels }\end{array}$ & $\begin{array}{c}\text { Direct } \\
\text { observations }\end{array}$ \\
\hline 3 & $\begin{array}{l}\text { Pedestals/rock } \\
\text { exposure and soil } \\
\text { depth }\end{array}$ & Yes & Past soil losses & $\begin{array}{l}\text { Overland flow and } \\
\text { runoff }\end{array}$ & $\begin{array}{l}\text { Soil depth } \\
\text { difference }\end{array}$ \\
\hline 4 & Armour layer & Yes & Past soil losses & $\begin{array}{l}\text { Overland flow, } \\
\text { heavy rainfall }\end{array}$ & $\begin{array}{c}\text { Depth of } \\
\text { armour layer }\end{array}$ \\
\hline 5 & $\begin{array}{l}\text { Plant/tree root } \\
\text { exposure }\end{array}$ & Yes & Past soil losses & $\begin{array}{l}\text { Overland flow and } \\
\text { runoff }\end{array}$ & $\begin{array}{l}\text { Soil depth } \\
\text { difference }\end{array}$ \\
\hline \multicolumn{6}{|c|}{ Additional Indicators } \\
\hline 6 & $\begin{array}{c}\text { Sediment in } \\
\text { drains/waterways }\end{array}$ & Yes & $\begin{array}{l}\text { Ongoing soil } \\
\text { loss }\end{array}$ & $\begin{array}{l}\text { Landslides, soil } \\
\text { loss }\end{array}$ & $\begin{array}{l}\text { Amount of } \\
\text { sediment }\end{array}$ \\
\hline 7 & $\begin{array}{l}\text { Enrichment } \\
\text { ratio/downslope }\end{array}$ & Yes & $\begin{array}{l}\text { Ongoing soil } \\
\text { loss }\end{array}$ & $\begin{array}{l}\text { The downslope } \\
\text { movement of soil }\end{array}$ & $\begin{array}{c}\text { Growth } \\
\text { differences }\end{array}$ \\
\hline 8 & $\begin{array}{l}\text { Soil texture and } \\
\text { color differences }\end{array}$ & Yes & $\begin{array}{l}\text { Ongoing soil } \\
\text { loss }\end{array}$ & $\begin{array}{l}\text { Soil loss and } \\
\text { overland flow }\end{array}$ & $\begin{array}{c}\text { Direct } \\
\text { observations }\end{array}$ \\
\hline
\end{tabular}

From the analysis, it can be suggested that the intensity and frequency of soil erosion and nutrient loss can be checked by implementing indigenous soil and water conservation (SWC) practices. The prevention of soil erosion on agricultural land was attributed to growing mixed crops, reducing slope length, and constructing various types of vegetative barriers on the slopes. As the vegetative barriers and crops grow, they cover the maximum area on the slopes and protect them from sheet and splash erosion. In many cases, mulching and green manure also helped farmers to conserve the soil and increase soil fertility and productivity. The roots of the crops and vegetative barriers have soil binding capacity and also stabilize the surface. In this context, it can be said that the barren land is more prone to soil loss as compared with the lands which are under various indigenous SWC practices and forestry.

\subsection{Farmers' Perceptiosn of Soil Erosion}

This section deals with the farmers' perceptions of land degradation and soil loss. Farm, field, and farmer-based participatory ways of assessing land degradation and its impact are needed to safeguard the farmers' valuable perspectives on conservation measures and their investment decisions with respect to soil and water conservation. Policies related to land management mostly rely on scientific reports based on quantitative research. Land degradation, particularly soil erosion, is complicated by a wide range of biophysical and socioeconomic factors, making it challenging to quantify using a few 
basic measures [45]. Vulnerable communities affected by land degradation require better policies to combat the problem. Qualitative data on socioeconomic factors and how farmers perceive land degradations could add value to existing policies, as well as lead to better policies and decision-making processes. Researchers from various disciplines have defined land degradation in a variety of ways and they view it as a critical and negative process for sustainability [46]. Numerous studies have emphasized land degradation but few studies have been based on the engagement and assessment of farmers $[47,48]$. It has been emphasized that land degradation does not operate in isolation, but rather in a synergistic manner $[49,50]$, the major drivers and phenomena that have been identified include climate change, biodiversity loss, cloud burst, population increase, as well as changing cropping patterns, intensification of agriculture, and small operational landholdings, which have led to pressure on the use of land and, in turn, land degradation. Assessing soil loss based on Stocking and Murnaghan's (2001) [38], the five major erosion indicators were all identified in the watershed. Among the other eight minor additional erosional indicators, three indicators were identified by the farmers during the field survey, which were sediment in drains/waterways, enrichment ratio/down slope, soil texture and color differences (Table 6).

The major causes of land degradation seem to be easy to comprehend based on common parlance, but they are complex in nature. They are closely linked to the natural ecosystem and the human social system. In the watershed, land degradation occurs in a variety of time and spatial scales, from a single storm to several decades, and from the effect of a single raindrop's location to entire fields in the watershed. Numerous advantages have been identified for the adoption of a grassroot level farmer-perspective approach to land degradation assessment. However, three main advantages, in this regard, are worth mentioning. First, assessment and measurements are more realistic, as they involve actual field-level processes; second, farmers, who are the ultimate clients and stakeholders, are involved in the identification process or erosion; and third, analysis and results of such methodology provide a far more practical view of the types of strategies that might be accepted by land users. Therefore, if there is a need for policy framework and impactful outcome, first-hand information must be identified, documented and advocated for decision making and professional analysis. This study lacked a time scale or historical analysis of the land degradation processes, which are the important starting point for land degradation assessment of any area. An analysis was not performed, as the majority of the areas of the watershed were occupied by forest and tiny patches of land had been utilized for agriculture and other land uses in the past. To exemplify the various components, Table 6 presents the erosion indicators, occurrence, causes, and measures identified by the farmers in the watershed. The major erosion indicators were those indicators that were clearly visible to the farmers. Information about these indicators was collected and discussed with the farmers, followed by ground truthing. Additional erosion indicators that were perceived as uncommon by farmers were also evaluated.

\subsubsection{Soil Loss: Farmers' Perspectives}

Indicators of soil erosion included loss of tilled soil (topsoil removal); the occurrence of rills, gullies and landslides; and sedimentation in the downslope fields. It is noteworthy that soil erosion takes place primarily because of overland flow and runoff, landslides, and sheet erosion, as mentioned by the majority of the respondents in the watershed. The farmers who participated in the field survey all agreed that they faced soil erosion, in some form or another, of their land. About 33\% of the farmers in all ecological zones responded that there was light or no soil losses in their field because the majority of the area was forested, with a strong base of traditional agroforestry and indigenous SWC measures in the watershed. About $17 \%$ of the farmers accepted moderate soil erosion in all ecological zones where intensive cultivation was practiced. Only 15-19\% of the farmers reported from high to extreme soil loss in the fields because of landslides, rills and gully formation, and terrace failure in the fields (Table 7). There were also a few farmers who expressed concern 
over soil erosion due to the intensification of agricultural practices, cropping patterns, and changes in land use practices.

Table 7. Assessment of soil loss based on farmers' perceptions of the watershed (\%).

\begin{tabular}{ccccc}
\hline S. No. & Soil Loss & Low $(\boldsymbol{n = 1 0 0 )}$ & Mid $(\boldsymbol{n}=\mathbf{1 0 0})$ & High $(\boldsymbol{n}=\mathbf{1 0 0})$ \\
\hline 1 & No & 33 & 35 & 42 \\
\hline 2 & Light & 29 & 31 & 25 \\
\hline 3 & Moderate & 19 & 15 & 18 \\
\hline 4 & High & 14 & 12 & 4 \\
\hline 5 & Extreme & 5 & 7 & 4 \\
\hline
\end{tabular}

In the watershed, soil erosion processes and their effects are not clearly visible and are not always easy to identify, except for landslides, rills and gullies. The erosion effects in production loss have not been quantified by researchers and were not substantial in the watershed. Although serious, these prominent types of soil erosion indicators are reversible with sustainable farming practices, sufficient remedial measures, and indigenous SWC practices.

\subsubsection{Productivity Loss}

Soil erosion has a direct correlation with the productivity loss of land and has been recognized as a process that needs not only biophysical examination but also socioeconomic understanding [51]. As per the discussion with the farmers, in the categories from no to light erosion, no productivity loss had occurred in the agricultural fields. In the categories from high to extreme soil erosion, productivity loss was medium. Despite productivity losses, agriculture fields have been maintained by several land management practices such as the use of mechanical (terracing, bunding, stone barriers, etc.), agronomic (mixed farming, vegetative barriers, agroforestry, etc.), and soil fertility measures (FYM, green manure, organic seed, etc.) in the watershed.

In general, land degradation, over the past decades, has increased and had an impact on the agricultural production capacity (for example, the production of large cardamom has declined). In each ecological zone, barren land was identified, while construction of new terraces was challenging to find. The general tendency, in the watershed, was that farmers had adopted floriculture and horticulture for better economic return and livelihood with the help of polyhouses. The farmers are well aware of land degradation and soil loss and consider it to be a serious threat to future generations. Farmers, during the discussion, were of the view that it was difficult to control land degradation due to the erratic nature of rainfall, declining land/man ratio, small land holdings, smaller land plots, loss of indigenous system knowledge, and climate change.

One of the major concerns was soil erosion of agricultural land, where during the rainy season farmers reported soil loss and nutrient loss from the watershed. During the focus group discussions, the farmers were asked to identify the indicators of land degradation that were prevalent in the watershed. Soil erosion, seasonal water shortage, population growth, small landholdings, and poverty are all factors that contribute to agricultural production problems, and the farmers are well aware of the situation, since declining productivity of soil affects their financial well-being. The farmers make investments in their fields by practicing several indigenous SWC measures such as mechanical, biological, and soil fertility measures to check soil erosion. Among the various conservation measures that have been adopted and practiced, farmers prefer agronomic treatments and measures because they are often less expensive and immediately address raindrop impact, runoff volumes, and water velocity while boosting infiltration and organic matter in the soil profile. The farmers indicated that agronomic practices have been utilized not just on agricultural land, but also to avoid slope failure, gully erosion, and landslides by planting 
bamboo trees in the watershed's most fragile and vulnerable sections. To control and reduce the impact of land degradation, the majority of the area should be treated with vegetative cover to prevent soil erosion and replace nutrient loss. Farmers need to invest in SWC measures to achieve promising results such as controlling overland flow and soil loss. Identification and measurement field-level analysis are essential for land degradation as it provides insight into what type of conservation measures are most promising and appropriate to implement for sustainable land management. As this assessment is based on the information and insight of the land user, it is worth integrating with the formulation of land management policies.

\section{Conclusions}

At present, several methodologies to assess land degradation and soil erosion are available such as the application of formula-based geospatial techniques and grid system monitoring; however, in this study, we have outlined erosion plots and rainfall (overland flow soil loss and nutrient loss) as well as farmers' perspectives of soil erosion and land degradation. These methodologies were adopted to obtain a clear picture of the status and processes of land degradation in the Rani Khola watershed. Globally, water is the main source of soil erosion, and the Rani Khola watershed is no exception. In the experiments conducted in the different land use classes, we recorded that overland flow, soil loss, and nutrient loss were the highest for barren land, while, in the agroforestry system, soil loss was the least even after having the second least overland flow. Indigenous agricultural and SWC practices are very strong in the watershed and help to conserve the changing soil surface morphology. Interventions such as planting horticultural trees and cultivating broom grass on terrace risers for soil fertility have significantly decreased soil loss. Farmers have applied green manure, FYM, and bio-composting in the fields to ensure nutrient availability in the watershed.

In areas where land degradation assessment is carried out for the first time, field monitoring and assessment techniques are best suited. Field-based observations with active farmer participation have proven to be useful and have various advantages for assessing land degradation and for understanding its impact in a region where such data are not available. However, this technique is only suitable for small study areas. An integrated approach of field-based observations and soil erosion modeling that uses multiple parameters would provide better data for larger regions with increased accuracy. In the present study area, further studies could also be done by using the results of the current study and integrating them with erosion models for better assessment of overall soil loss in the region.

Farmers of the watershed were actively involved in the fieldwork and assessment that provided a real picture of the processes that are happening in the field in a relatively short time. The assessment of land degradation involved farmers and local people from all the ecological zones, and it was found that the majority of the respondents (33\%) of the watershed expressed that their land fell under the "no to slight" erosion categories. The areas with high and extreme soil erosion were comparatively smaller than the areas with the other erosion classes. Therefore, in this context, it is clear that, when formulating policy, decision-makers and conservation professionals must incorporate farmers' perspectives in assessing soil loss and adopt conservation measures to safeguard the land.

Author Contributions: Conceptualization, P.K.M., S.C.R.; methodology, P.K.M., A.R.; software, P.K.M., A.R.; mapping, A.R., A.T.; formal analysis, P.K.M., A.R., S.C.R.; data collection, P.K.M., A.R.; data analysis, P.K.M., A.R., S.C.R., A.T.; writing—original draft preparation, P.K.M., A.R.; writingreview and editing, P.K.M., A.R., K.A., S.C.R., A.T.; visualization, P.K.M., A.T., K.A. All authors have read and agreed to the published version of the manuscript.

Funding: This research was funded by Indian Council of Social Science Research (ICSSR) New Delhi, India for financial support [F. No 02/298/2016/17/ICSSR/RP] and Researchers Supporting Project number (RSP-2021/351), King Saud University, Riyadh, Saudi Arabia. 
Institutional Review Board Statement: Not applicable.

Informed Consent Statement: Informed consent was obtained from all respondents involved in the study.

Data Availability Statement: The data presented in this study are available on request from the corresponding author. The data are not publicly available due to privacy or ethical restrictions.

Acknowledgments: The authors highly appreciated the farmers who were involved in the field survey for their valuable time. The assistance offered by the village leaders during all the focus group discussions and data collection processes is also highly acknowledged. The authors are thankful to the Indian Council of Social Science Research (ICSSR) New Delhi, India for financial support (F. No 02/298/2016/17/ICSSR/RP) to carry out the research. Deep thanks and gratitude to the Researchers Supporting Project Number (RSP-2021/351), King Saud University, Riyadh, Saudi Arabia for funding this research article.

Conflicts of Interest: The authors declare no conflict of interest.

\section{References}

1. Pimentel, D.; Harvey, C.; Resosudarmo, P.; Sinclair, K.; Kurz, D.; McNair, M.; Crist, S.; Shpritz, L.; Fitton, L.; Saffouri, R.; et al. Environmental and economic costs of soil erosion and conservation benefits. Science 1995, 267, 1117-1123. [CrossRef] [PubMed]

2. Mishra, P.K.; Rai, S.C. Use of indigenous soil and water conservation practices among farmers in Sikkim Himalaya. Indian J. Tradit. Knowl. 2013, 12, 454-464.

3. IPCC. Summary for policymakers. In Climate Change and Land: An IPCC Special Report on Climate Change, Desertification, Land Degradation, Sustainable Land Management, Food Security, and Greenhouse Gas Fluxes in Terrestrial Ecosystems; IPCC: Geneva, Switzerland, 2019.

4. GSP. Global Soil Partnership Endorses Guidelines on Sustainable Soil Management 2017. Available online: http:/ /www.fao.org/ global-soilpartnership/resources/highlights/detail/en/c/416516/ (accessed on 15 October 2021).

5. Adimassu, Z.; Langan, S.; Johnston, R.; Mekuria, W.; Amede, T. Impacts Of Soil And Water Conservation Practices On Crop Yield, Run-Off, Soil Loss And Nutrient Loss In Ethiopia: Review And Synthesis. Environ. Manag. 2016, 59, 87-101. [CrossRef] [PubMed]

6. Ma, X.; Li, Y.; Li, B.; Han, W.; Liu, D.; Gan, X. Nitrogen And Phosphorus Losses By Runoff Erosion: Field Data Monitored Under Natural Rainfall In Three Gorges Reservoir Area, China. CATENA 2016, 147, 797-808. [CrossRef]

7. Bhattacharyya, R.; Ghosh, B.N.; Mishra, P.K.; Mandal, B.; Rao, C.S.; Sarkar, D.; Das, K.; Anil, K.S.; Lalitha, M.; Hati, K.M.; et al. Soil Degradation in India: Challenges and Potential Solutions. Sustainability 2015, 7, 3528-3570. [CrossRef]

8. Prasad, B.; Jaiswal, R.K.; Tiwari, D.H. Assessment of environmentally stressed areas for soil conservation measures using USPED model. Int. J. Eng. Res. 2014, 3, 58-63.

9. Issaka, S.; Ashraf, M. Impact Of Soil Erosion And Degradation On Water Quality: A Review. Geol. Ecol. Landsc. 2017, 1, 1-11. [CrossRef]

10. Lal, R. Soil Erosion Impact On Agronomic Productivity And Environment Quality. Crit Rev. Plant. Sci. 1998, 17, 319-464. [CrossRef]

11. Lal, R. Restoring Soil Quality To Mitigate Soil Degradation. Sustainability 2015, 7, 5875-5895. [CrossRef]

12. UNEP/ISRIC. World Map on Status of Human Induced Soil Degradation; UNEP: Nairobi, Kenya, 1990; scale 1:10,000,000.

13. Stefanidis, S. Estimation of the mean annual sediment discharge in fire affected watersheds. Silva Balc. 2011, 12, 91-96.

14. Efthimiou, N.; Psomiadis, E.; Panagos, P. Fire severity and soil erosion susceptibility mapping using multi-temporal Earth Observation data: The case of Mati fatal wildfire in Eastern Attica, Greece. Catena 2020, 187, 104320. [CrossRef] [PubMed]

15. Narayana, V. Downstream Impacts Of Soil Conservation In The Himalayan Region. Mt. Res. Dev. 1987, 7, 287. [CrossRef]

16. Jain, S.; Kumar, S.; Varghese, J. Estimation of Soil Erosion for a Himalayan Watershed Using GIS Technique. Water Res. Manag. 2001, 15, 41-54. [CrossRef]

17. Nibanupudiand, H.K.; Rawat, P. Environmental concerns for drr in hindu-kush himalaya region. In Ecosystem Approach to Disaster Risk Reduction; National Institute of Disaster Management: New Delhi, India, 2012; Volume 85.

18. Pimentel, D. Soil Erosion And The Threat To Food Security And The Environment. Ecosys. Health 2000, 6, 221-226. [CrossRef]

19. ICIMOD. Constraints and opportunities. In Proceedings of the International Symposium on Mountain Environment and Development, International Centre for Integrated Mountain Development, Kathmandu, Nepal, 1994.

20. Kayastha, P.; Dhital, M.R.; De Smedt, F. Application of the analytical hierarchy process (AHP) for landslide susceptibility mapping: A case study from the Tinau watershed, west Nepal. Comput. Geosci. 2013, 52, 398-408. [CrossRef]

21. Ghimire, S.K.; Higaki, D.; Bhattarai, T.P. Estimation of soil erosion rates and eroded sediment in a degraded catchment of the Siwalik Hills, Nepal. Land 2013, 2, 370-391. [CrossRef]

22. Paudel, K.P.; Andersen, P. Assessing rangeland degradation using multi temporal satellite images and grazing pressure surface model in Upper Mustang, Trans Himalaya, Nepal. Remote. Sens. Environ. 2010, 114, 1845-1855. [CrossRef]

23. Uddin, K.; Abdul Matin, M.; Maharjan, S. Assessment Of Land Cover Change And Its Impact On Changes In Soil Erosion Risk In Nepal. Sustainability 2018, 10, 4715. [CrossRef] 
24. CSWCR\&TI. 2030 vision document of the central soil and water conservation research and training institute. In Vision, 2030; Allied Publisher: Dehradun, India, 2011; pp. 1-46.

25. Yusof, F.M.; Jamil, N.R.; Aini, N.; Manaf, L.A. Land use change and soil loss risk assessment by using geographical information system (GIS): A case study of lower part of Perak River. In Proceedings of the IOP Conference Series: Earth and Environmental Science, Ancona, Italy, 1-2 October 2018; IOP Publishing LTD: Bristol, UK, 2019.

26. Patric, J.H. Soil erosion in the eastern forest. J. For. 1976, 74, 671-677.

27. Rai, S.C.; Sharma, E. Comparative assessment of runoff characteristics under different land-use pattern within a Himalayan watershed. Hydrol. Process. 1998, 12, 2235-2248. [CrossRef]

28. Abdel Rahman, M.A.; Natarajan, A.; Hegde, R.; Prakash, S.S. Assessment of land degradation using comprehensive geostatistical approach and remote sensing data in GIS-model builder. Egypt J. Remote. Sens. Space Sci. 2019, 22, 323-334.

29. Stefanidis, S.; Chatzichristaki, C.; Stefanidis, P. An ArcGIS toolbox for estimation and mapping soil erosion. J. Environ. Prot. Ecol. 2021, 22, 689-696.

30. Panagos, P.; Ballabio, C.; Himics, M.; Scarpa, S.; Matthews, F.; Bogonos, M.; Borrelli, P. Projections of soil loss by water erosion in Europe by 2050. Environ. Sci. Policy 2021, 124, 380-392. [CrossRef]

31. Hateffard, F.; Mohammed, S.; Alsafadi, K.; Enaruvbe, G.O.; Heidari, A.; Abdo, H.G.; Rodrigo-Comino, J. CMIP5 climate projections and RUSLE-based soil erosion assessment in the central part of Iran. Sci. Rep. 2021, 11, 1-17.

32. Oliveira, P.T.S.; Nearing, M.A.; Wendland, E. Orders of magnitude increase in soil erosion associated with land use change from native to cultivated vegetation in a Brazilian savannah environment. Earth Surf. Process. Landf. 2015, 40, 1524e1532. [CrossRef]

33. Oliveira, P.; Wendland, E.; Nearing, M.; Scott, R.; Rosolem, R.; da Rocha, H. The Water Balance Components Of Undisturbed Tropical Woodlands In The Brazilian Cerrado. Hydrol. Earth Syst. Sci. 2015, 19, 2899-2910. [CrossRef]

34. Anache, J.; Wendland, E.; Rosalem, L.; Youlton, C.; Oliveira, P. Hydrological Trade-Offs Due To Different Land Covers And Land Uses In The Brazilian Cerrado. Hydrol. Earth Syst. Sci. 2019, 23, 1263-1279. [CrossRef]

35. Mishra, P.; Rai, A.; Rai, S. Agronomic Measures In Traditional Soil And Water Conservation Practices In The Sikkim Himalaya, India. Am. Res. J. Agric. 2019, 5, 1-16. [CrossRef]

36. Singh, J.; Pandey, A.; Pathak, P. A Hypothesis To Account For The Major Pathway Of Soil Loss From Himalaya. Environ. Conserv. 1983, 10, 343-345. [CrossRef]

37. Rai, S.C.; Sharma, E. Hydrology and nutrient flux in an agrarian watershed of the Sikkim Himalaya. J. Soil Water Conserv. 1998, 53, 125-132.

38. Stocking, M.A.; Murnaghan, N. Handbook for Field Assessment of Land Degradation; Earthscan: London, UK, 2001.

39. Mishra, P.K.; Rai, A.; Abdelrahman, K.; Rai, S.C.; Tiwari, A. Analysing Challenges and Strategies in Land Productivity in Sikkim Himalaya, India. Sustainability 2021, 13, 11112. [CrossRef]

40. Mishra, P.; Rai, A.; Rai, S.C. Land use and land cover change detection using geospatial techniques in the Sikkim Himalaya, India. Egypt. J. Remote. Sens. Space Sci. 2020, 23, 133-143. [CrossRef]

41. Paustian, K.; Andrén, O.; Janzen, H.; Lal, R.; Smith, P.; Tian, G.; Tiessen, H.; Noordwijk, M.; Woomer, P. Agricultural Soils As A Sink To Mitigate Co2emissions. Soil Use Manag. 1997, 13, 230-244. [CrossRef]

42. Drinkwater, L.; Wagoner, P.; Sarrantonio, M. Legume-Based Cropping Systems Have Reduced Carbon And Nitrogen Losses. Nature 1998, 396, 262-265. [CrossRef]

43. Sharma, E.; Sharma, R.; Singh, K.; Sharma, G. A Boon for Mountain Populations. Mt. Res. Dev. 2000, $20,108-111$.

44. Mishra, P.K. Assessment of Run-off and Soil Loss under different Land-use Practices in a HimalayanWatershed, India. Am. Res. J. Humanit. Soc. Sci. 2017, 3, 3.1-10.

45. Stocking, M. Field assessment of erosion and soil productivity from the perspective of the land user. In Renewable Natural Resources Management for Mountain Communities; Stocking, M., Helleman, H., White, R., Eds.; ICMOD: Kathmandu, Nepal, 2005; Chapter 11; pp. 149-158.

46. Pulido, J.; Bocco, G. Local Perception Of Land Degradation In Developing Countries: A Simplified Analytical Framework Of Driving Forces, Processes, Indicators And Coping Strategies. Living Rev. Landsc. Res. 2014, 8. [CrossRef]

47. Teshome, A.; De Graaff, J.; Ritsema, C.; Kassie, M. Farmers' Perceptions About The Influence Of Land Quality, Land Fragmentation And Tenure Systems On Sustainable Land Management In The North Western Ethiopian Highlands. Land Degrad. Dev. 2014, 27, 884-898. [CrossRef]

48. Tesfahunegn, G.; Ayuk, E.; Adiku, S. Farmers' Perception On Soil Erosion In Ghana: Implication For Developing Sustainable Soil Management Strategy. PLoS ONE 2021, 16, e0242444. [CrossRef]

49. Bisaro, A.; Kirk, M.; Zdruli, P.; Zimmermann, W. Global drivers setting desertification research priorities: Insights from a stakeholder consultation forum. Land Degrad. Dev. 2014, 25, 5-16. [CrossRef]

50. Borrelli, P.; Robinson, D.; Fleischer, L.; Lugato, E.; Ballabio, C.; Alewell, C.; Meusburger, K.; Modugno, S.; Schütt, B.; Ferro, V.; et al. An Assessment Of The Global Impact Of 21St Century Land Use Change On Soil Erosion. Nat. Commun. 2017, 8. [CrossRef] [PubMed]

51. Boardman, J.; Poesen, J.; Evans, R. Socio-economic factors in soil erosion and conservation. Environ. Sci. Policy 2003, 6, 1-6. [CrossRef] 